\title{
ASSESSMENT OF THE GENETIC DIVERSITY BETWEEN TWO VARIETIES OF WONDERBOOM (FICUS SALICIFOLIA VAHL.) BY USING SIMPLE SEQUENCE REPEAT (SSR) MARKERS
}

\author{
AMEDJKOUH, H. ${ }^{1,2^{*}}-$ BOUGUEDOURA, N. ${ }^{1}$ \\ ${ }^{1}$ Research Laboratory of Arid Zones, Faculty of Biological Sciences, University of Sciences and \\ Technology Houari Boumediene (USTHB), PO Box 113, El Alia 16111, Bab-Ezzouar, Algiers, \\ Algeria \\ ${ }^{2}$ Department of Biology of Populations and Organisms, Faculty of Sciences of Nature and Life, \\ University of Blida I, PO Box 270, Soumaa Road, Blida, Algeria \\ *Corresponding author \\ e-mail: hafida.lrza@gmail.com; phone: +213-771-029-173 \\ (Received 13 ${ }^{\text {th }}$ Apr 2021; accepted 12 ${ }^{\text {th }}$ Aug 2021)
}

\begin{abstract}
This study aims to determine the genetic diversity of Ficus salicifolia varieties collected from (Tamanrasset) Southern Algeria. Currently, little is known about the genetic variability between two varieties "Teloukat" and "Eucalyptoïdes". Thirty-nine fig trees were examined by using six simple sequences repeat (SSR) markers. In total 64 alleles were observed in the samples of two varieties. The number of alleles per locus ranged from seven to eighteen, with an average of 10.66 alleles per locus. The mean values of heterozygosities observed and expected were 0.61 and 0.74 respectively. The positives Fis (Wright inbreeding coefficient) value obtained with (MFC2, MFC8, LMFC26, LMFC30 and FSYCO1) loci indicated deficiency of heterozygote. Considering the PIC (polymorphic information content) results, 5 markers (MFC2, MFC8, LMFC26, LMFC30 and FSYCO1) were classified as highly informative (PIC > 0.5). The phylogenetic diagram performed using the Unweighted Pair Grouping Method with Arithmetic average (UPGMA) showed significant intraspecific polymorphism between the two varieties which was confirmed by Factorial Correspondence Analysis (FCA).
\end{abstract}

Keywords: Ficus salicifolia, Tamanrasset, SSR markers, heterozygote, UPGMA, intraspecific polymorphism

\section{Introduction}

Ficus (figs) is a genus which includes economically important fruit species (Ficus carica), present worldwide, with 750 species in total from Ficus genus occurring throughout tropical and subtropical regions, almost of which are evergreen trees, shrubs or lianas producing the latex and enclosed inflorescences (Berg, 1989).

In Southern Algeria (Tamanrasset), the Ficus genus is commonly represented by Ficus salicifolia Vahl., an endemic species of central Sahara (Ozenda, 1977), which is highly fragmented and rarely exceeds 30 individuals making them locally endangered. It develops intermediate growth forms between shrubs and tree, with small (10 to $20 \mathrm{~mm}$ diameter) ripe dark red figs which are edible for humans and animals, two varieties are cultivated "variety Teloukat" and "variety Eucalyptoïdes" (Battandier and Trabut, 1912). Both grow at high altitudes (1400 to $2700 \mathrm{~m}$ ) along Rockies flaws ravines under arid conditions (temperature from 16 to $30{ }^{\circ} \mathrm{C}$, rainfall less than $50 \mathrm{~mm}$ per year).

Several homonyms and synonyms of these trees are used by aboriginals, which make their characterization very difficult, because there is not yet real recognition or information on their ecological or genetic divergence (Sahki and Sahki, 2004). Currently, little is known about genetic diversity of Ficus salicifolia varieties except 
morphological characters description which are still unreliable for the unambiguously identification of two varieties (Teloukat and Eucalyptoïdes). In addition, variation in phenotypic characters does not necessarily reflect the genetic diversity of the population (Bagavathiannan et al., 2010). Further, most morphological traits are influenced by environmental factors (Teoman et al., 2017). In this investigation, we refer to groups of trees in natural habitats to assess their genetic diversity.

Since, objectivity is essential for the identification; morphological traits can be unreliable for genetic plant identification and characterization (Ercisli et al., 2008). To preserve and improve existing plant genetic resources under harsh conditions, it will be helpful to evaluate genetic diversity and molecular markers permits a more rapid and reliable approach, so, they offer numerous advantages over conventional alternatives based on morphological traits; these markers are stable and detectable in all plant tissues, regardless of environmental conditions (Leal et al., 2010; Do Val et al., 2013).

Previous studies have showed that DNA marker technologies provided an effective tool for the conservation of fig genetic resources, such as random amplified polymeric DNA (RAPD) (Dalkilic et al., 2011; Baziar et al., 2018), restriction fragment length polymorphism (RFLP) (Khadari et al., 2005), amplified fragment length polymorphism (AFLP) (Baraket et al., 2011) and single sequence repeat (SSR) (Ferrara et al., 2016; Fu et al., 2017). To study the genetic diversity, the SSR markers were used regarding their highly polymorphic, co-dominant and abundance in the genome (Fu et al., 2017; Hladnik et al., 2018). Microsatellite markers have been widely used for the analysis of genetic diversity and they play an essential role in all aspects of plant selection; as: apple (Malus domestica) (Pikunova et al., 2018); apricot (Prunus armeniaca) (Köse et al., 2017); peach (Prunus persica) (Licea-Moreno et al., 2019); olive (Olea europaea ssp europaea) (Ben Mohamed et al., 2017) and (Olea europaea ssp laperrinei) (BaaliCherif and Besnard, 2005). SSR markers are also widely used for the evaluation of the diversity studies and characterization of Fig species trees (Khadari et al., 2004; Essid et al., 2015; Boudchicha et al., 2018).

The apparent ambiguity in the taxonomic classification of two varieties not distinct morphologically (Teloukat and Eucalyptoïdes), directed us to the use of molecular markers; therefore, the aim of this present study is to determine the genetic diversity within individuals of Ficus salicifolia enabling to establish the relationship between the two varieties. On the other hand, to define a conservation strategy, the genetic diversity of this species has to be investigated.

\section{Materials and methods}

\section{Plant material}

Leaves samples of thirty-nine individuals of Ficus salicifolia (Fig. 1) of both varieties: (Eucalyptoïdes and Telloukat) were collected randomly from a natural habitat of six zones (Table 1; Appendix 1; Fig. 2) located in Ahaggar (Tamanrasset: 2257’42" north, $5^{\circ} 11^{\prime} 51^{\prime \prime}$ east) in the central Sahara of Southern Algeria.

\section{Molecular markers}

\section{DNA extraction}

Total genomic DNA was extracted as described by Khadari et al. (2004) using $200 \mathrm{mg}$ of leaves dried in silica gel, according to the DNeasy Plant Mini Kit (QIAGEN, 
Courtaboeuf, France) optimized by adding 1\% polyvinylpyrrolidone (PVP 40.000) to the buffer AP1.

DNA was quantified using spectrometric method (Sambrook et al., 1989): the absorbance was recorded at $260 \mathrm{~nm}$ wavelength (Spectrophotometer UV mini-1240, Shimadzu Japan). The relative purity of extracted DNA was estimated after electrophoresis with $0.7 \%$ agarose gel stained by $0.2 \mu \mathrm{g} .1^{-1}$ Ethidium Bromide and immersed in $90 \mathrm{mM}$ Tris-Borate, $\mathrm{pH} 8$ and $10 \mathrm{mM}$ Ethyldiamine Tetra-acetic Acid (EDTA), the DNA samples were visualized under ultraviolet light.

\section{SSR markers}

The 6 SSR markers were selected due to their polymorphism level, the high quality of amplification reproducibility and transferability, since five SSR markers were developed for a common fig (Ficus carica L): LMFC26, LMFC30 (Giraldo et al., 2005), MFC2 (Khadari et al., 2001) and MFC8, MFC12 (Achtak et al., 2009), and a marker FSYCO1 was developed for Ficus sycomorus (Ahmed et al., 2007). The details of each marker are shown in Table 2.
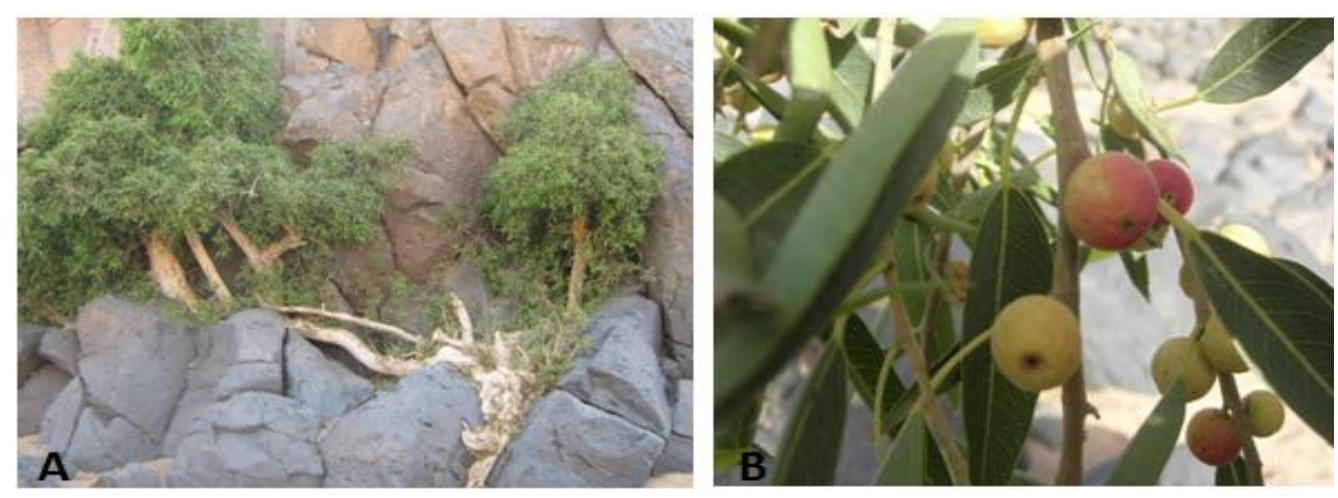

Figure 1. Morphology of Ficus salicifolia in arid zones (Tamanrasset). A: External morphology of the tree. B: morphological appearance of some vegetative (leaves, shoots) and reproductive (fruits) parts

Table 1. List of individual fig trees with GPS data

\begin{tabular}{c|c|c|c|c}
\hline $\begin{array}{c}\text { Local name of } \\
\text { collection zones }\end{array}$ & $\begin{array}{c}\text { Individuals } \\
\text { number }\end{array}$ & Code of trees & Altitude (m) & Latitude/longitude \\
\hline TIT & 10 & $\begin{array}{c}\text { from Fs01 to Fs10 } \\
\text { Variety Teloukat }\end{array}$ & From 1081 to 1088 & $22^{\circ} 57^{\prime} 46^{\prime \prime} / 05^{\circ} 09^{\prime} 76^{\prime \prime}$ \\
\hline IH-AGHI & 05 & $\begin{array}{c}\text { from Fs11 to Fs15 } \\
\text { Variety Teloukat }\end{array}$ & From 1093 to 1095 & $23^{\circ} 04^{\prime} 10^{\prime \prime} / 05^{\circ} 12^{\prime} 85^{\prime \prime}$ \\
\hline IN-HOUTER & 01 & $\begin{array}{c}\text { Fs16 } \\
\text { Variety Eucalyptoides }\end{array}$ & 1455 & $23^{\circ} 04^{\prime} 73^{\prime \prime} / 05^{\circ} 22^{\prime} 85^{\prime \prime}$ \\
\hline TADADINE & 03 & $\begin{array}{c}\text { from Fs17 to Fs19 } \\
\text { Variety Eucalyptoides }\end{array}$ & From 1315 to 1350 & $22^{\circ} 49^{\prime} 42^{\prime \prime} / 05^{\circ} 57^{\prime} 33^{\prime \prime}$ \\
\hline IN-ZEBIB & 18 & $\begin{array}{c}\text { from Fs20 to Fs37 } \\
\text { Variety Teloukat and } \\
\text { Variety Eucalyptoides }\end{array}$ & From 1425 to 1459 & $22^{\circ} 48^{\prime} 36^{\prime \prime} / 05^{\circ} 37^{\prime} 49^{\prime \prime}$ \\
\hline AMEZEDJINE & 02 & $\begin{array}{c}\text { from Fs38 to Fs39 } \\
\text { Variety Teloukat }\end{array}$ & From 1162 to 1165 & $22^{\circ} 36^{\prime} 96^{\prime \prime} / 05^{\circ} 24^{\prime} 46^{\prime \prime}$ \\
\hline
\end{tabular}

Fs, Ficus salicifolia 


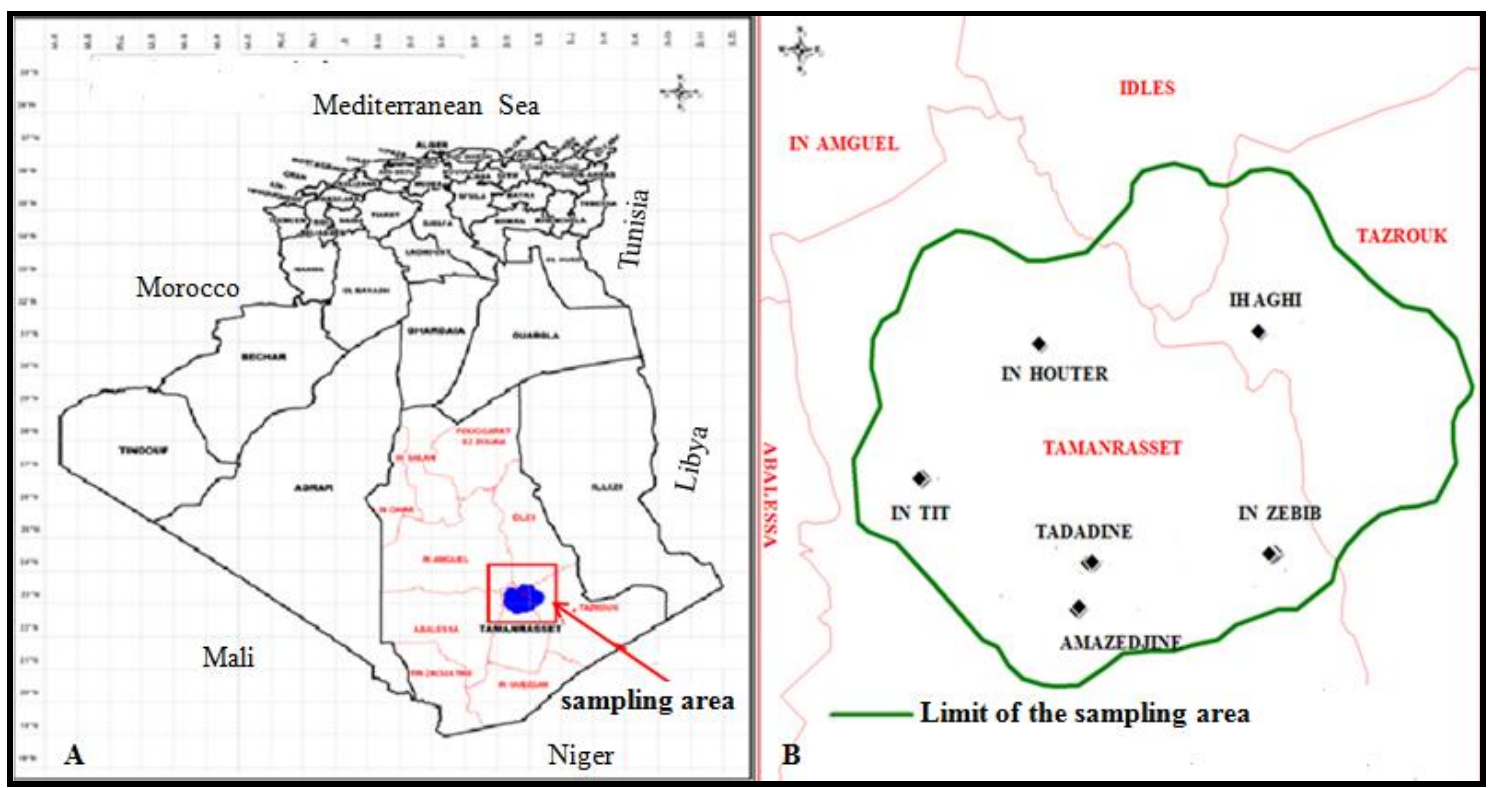

Figure 2. Map showing location of sampling areas, in Tamanrasset (southern Algeria). A: Algeria within north Africa on a globe (www.Alamy.com). B: Stations of collection

Table 2. Fig SSR primer sequences used

\begin{tabular}{c|c|c|c|c}
\hline $\begin{array}{c}\text { Microsatellite } \\
\text { primers }\end{array}$ & Repeat motif & $\begin{array}{c}\text { Primer sequences 5' to 3' }(\mathbf{F}) \\
(\text { Forward })\end{array}$ & $\begin{array}{c}\text { Primer sequences 5' to 3' }(\mathbf{R}) \\
\text { (Reverse) }\end{array}$ & $\begin{array}{c}\text { Tm } \\
\left({ }^{\circ} \mathbf{C}\right)\end{array}$ \\
\hline MFC 2 & $(\mathrm{AC})_{18}(\mathrm{AT})_{7}$ & GCTTCCGATGCTGCTCTTA & TCGGAGACTTTTGTTCAAT & 55 \\
FSYCO1 & $(\mathrm{A})_{16}(\mathrm{GAAA})_{8}$ & CAAATGAAAAACACAAATTTGCCAA & TGCAAGTACTAATTCCTCTGCCGTG & 55 \\
LMFC26 & $(\mathrm{TC})_{11}$ & ATGTTATAGTTGAGTGAGGATAA & AAATAGTGGATCTTGCATGT & 55 \\
MFC8 & $(\mathrm{CA})_{9} \mathrm{TA}(\mathrm{CA})_{14}(\mathrm{TA})_{6}$ & GTGGCGTCGTCTCTAATAAT & TATTCTATGCTGTCTTATGTCA & 50 \\
MFC12 & $/$ & TATCACGGCGGTCTAACTCTGC & CTCCTCATCCCCCTCCCAACT & 50 \\
LMFC30 & $(\mathrm{CT})_{14}$ & TTGTCCGTTTCTTATACAAT & TCTTTTTAGGCAGATGTTAG & 55 \\
\hline
\end{tabular}

\section{PCR amplification and genotyping procedure}

Amplification was carried out using the PCR conditions of fig studies (Khadari et al., 2004; Achtak et al., 2009) by conducting polymerase chain reaction (PCR) amplification in a total volume of $20 \mu \mathrm{L}$ containing PCR buffer $[10 \mathrm{mM}$ Tris $-\mathrm{HCl}(\mathrm{pH}$ 8.3), $50 \mathrm{mM} \mathrm{KCl}, 0.1 \%$ Triton X-100 (Perkin Elmer, Milan, Italy) and 0.02\% gelatin], $20 \mathrm{ng}$ of fig genomic DNA, $2 \mathrm{mM} \mathrm{MgCl}, 0.2 \mathrm{mM}$ of each dNTP, 1 to 4 pmol for dyelabeled primers [fluorescent phosphoramidites FAM, HEX (MWG Biotech, Courtaboeuf, France) or NED (Applied Biosystems, Courtaboeuf, France) at the 5' position], and 2 to $8 \mathrm{pmol}$ for unlabeled, $1 \mathrm{U}$ of Taq DNA polymerase (Sigma-Aldrich, Lyon, France).

Amplification reactions were performed in a thermocycler (MJ Research, Watham, MA). The PCR conditions were as follows: after 5 min denaturation at $94{ }^{\circ} \mathrm{C}, 35$ cycles were performed with $30 \mathrm{~s}$ denaturation at $94{ }^{\circ} \mathrm{C} ; 1 \mathrm{~min}$ annealing at $55{ }^{\circ} \mathrm{C} ; 1 \mathrm{~min}$ elongation at $72{ }^{\circ} \mathrm{C}$; and a final extension step of $7 \mathrm{~min}$ elongation at $72{ }^{\circ} \mathrm{C}$. PCR products $(2 \mu \mathrm{l})$ was mixed with 7.9 formamide and $0.1 \mu$ l Gensize 400HD (Rox Size Standard; Applied Biosystems) and were separated using capillary electrophoresis on an ABI prism 3130 XL automatic DNA sequencer (Applied Biosystems). 
Electopherograms were then analyzed with the Gene Mapper 3.7 software (Applied Biosystems). Allele peak profiles were detected at each locus and genotype, manually reviewed and final sizes were rounded to the nearest full number representing the final called allele length.

\section{Data analysis}

For each SSR locus, alleles were detected and identified by allele size in base pair (bp) and the number of alleles per locus (A). Different indices of genetic diversity were estimated for each locus: observed heterozygosity (Ho), expected heterozygosity (He), and the Wright inbreeding coefficient (Fis) were computed using the software Genetix 4.5 (Weir and Cockerham, 1984; Belkhir et al., 2004). Polymorphic Information Content (PIC) was calculated using CERVUS 3.03 (Marshall, 1998).

Individuals in relationships were represented by dendrogram constructed from Nei's standard genetic distances (Tamura and Nei, 1993); this dendrogram was generated using Unweighted Pair-Group Method using Arithmetic average (UPGMA) (Saitou and Nei, 1987) and was constructed using the software Clustering Calculator (Brzustowski, 2002). The Factorial Correspondence Analysis (FCA) was also recorded on individual plant using Darwin 3.6 software (Perrier et al., 2003).

\section{Results}

\section{Simple sequence repeat polymorphism}

A total of 64 alleles were amplified and the number of alleles per marker ranged from five to eighteen with an average of 10.66 alleles and amplification fragment sizes between 135 and 294 nucleotides (Table 3).

Table 3. Locus name and genetic parameters of the South-Algerian fig trees

\begin{tabular}{c|c|c|c|c|c|c}
\hline Locus & N & Size range & Ho & He & Fis & PIC \\
\hline MFC2 & 10 & $140-166$ & 0.59 & 0.76 & 0.171 & 0.74 \\
FSYCO1 & 13 & $135-166$ & 0.79 & 0.85 & 0.052 & 0.84 \\
LMFC26 & 6 & $217-242$ & 0.36 & 0.62 & 0.272 & 0.58 \\
MFC8 & 18 & $147-206$ & 0.47 & 0.88 & 0.433 & 0.88 \\
MFC12 & 5 & $151-174$ & 0.82 & 0.54 & -0.538 & 0.45 \\
LMFC30 & 12 & $264-294$ & 0.65 & 0.75 & 0.125 & 0.72 \\
\hline Mean & 10.66 & $/$ & 0.61 & 0.73 & 0.085 & 0.70 \\
\hline
\end{tabular}

$\mathrm{N}$, Number of alleles; Ho, Observed heterozygosity; He, Expected heterozygosity; Fis, Wright inbreeding coefficient; PIC, Polymorphic information content

The highest number of alleles (18) was detected at the MFC8, that corresponds with the highest values of the genetic diversity parameters $(\mathrm{He}=0.88$, Fis $=0.43$, PIC $=0.88$ ), whereas the lowest number (5 alleles) was obtained for the MFC12.

The values for observed $(\mathrm{Ho})$ and expected $(\mathrm{He})$ heterozygosities ranged from 0.36 to 0.82 , and from 0.54 to 0.88 respectively, the average genetic diversity $(\mathrm{He}=0.74)$ was higher than $(\mathrm{Ho}=0.61)$; according to the Hardy-Weinberg $(\mathrm{HW})$ equilibrium, heterozygote excess $(\mathrm{Ho}>\mathrm{He})$ was observed for the MFC12 locus, whereas a 
deficiency of heterozygote (Ho < He) was observed in MFC8, MFC2, LMFC26, LMFC30 and FSYCO1 loci.

The wright inbreeding coefficient (Fis) values, could be explained by heterozygous deficiency due to positive values of MFC8, MFC2, LMFC26, LMFC30 and FSYCO1 loci, and negative value of MFC12 locus (-0.538), indicating heterozygote excess (Table 3).

The average value of PIC (polymorphic information content) for the primer sets was 0.70 , ranging from 0.45 for MFC12 to 0.88 for MFC8. Considering the PIC results, 5 markers (MFC2, MFC8, LMFC26, LMFC30 and FSYCO1) showed PIC values greater than 0.5 , therefore, these primers were classified as highly informative and have power for analyzing the genetic variability of Ficus salicifolia.

\section{Genetic relationship between two varieties of Ficus salicifolia}

To represent the relationships between two varieties of Ficus salicifolia, a cluster analysis was used to plot a dendrogram based on Nei's genetic distance (Fig. 3): five main clusters are evident.

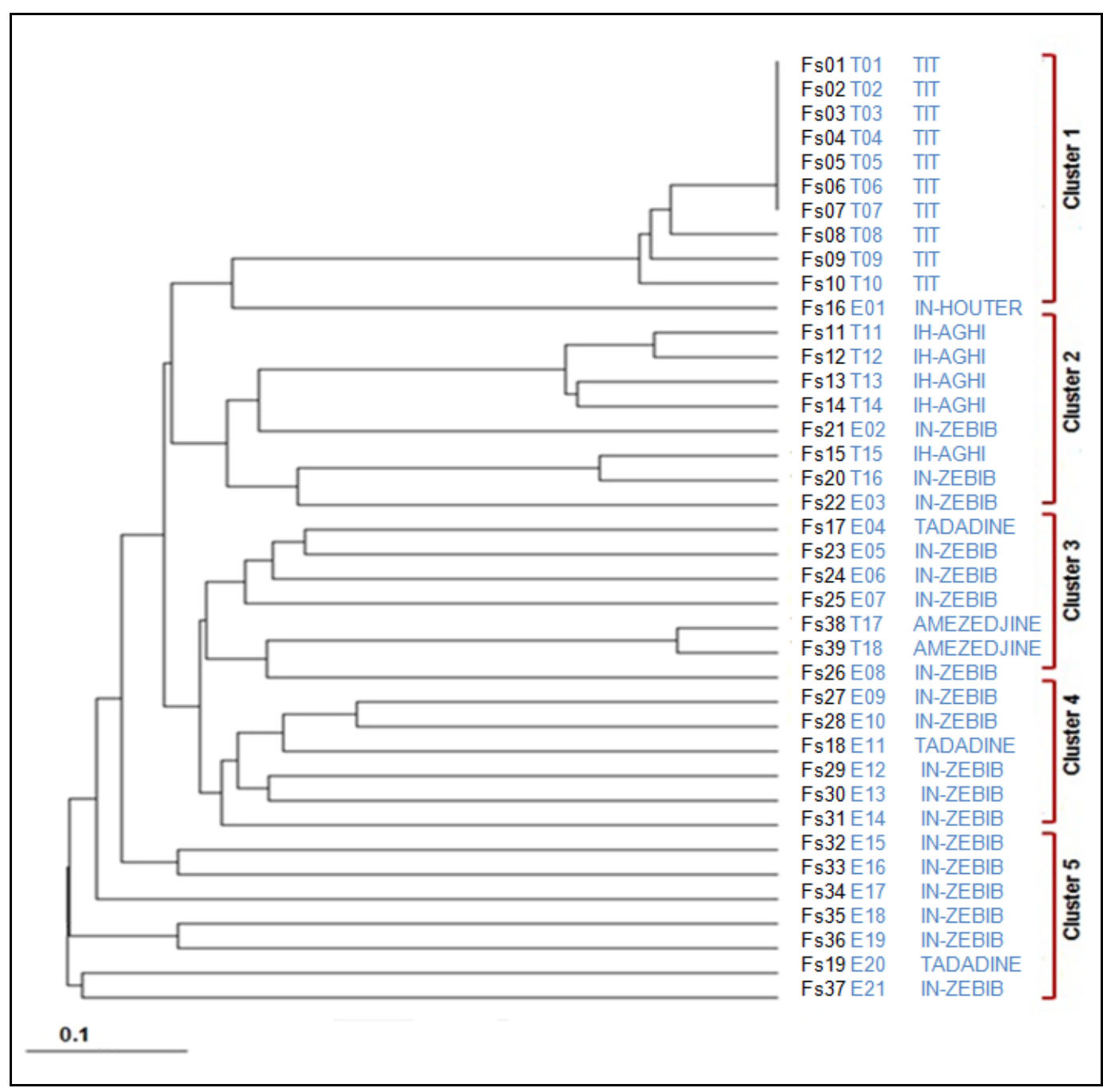

Figure 3. UPGMA (unweighted pair-group method by arithmetic average) dendrogram based on Nei's genetic distance obtained from analysis of simple sequence repeats data for 39 south Algerian fig trees. Fs, Ficus salicifolia; T, Teloukat; E, Eucalyptoides 
The first cluster grouped all individuals of Ficus salicifolia, variety Teloukat located at Tit (Fs01, Fs02, Fs03, Fs04, Fs05, Fs06, Fs07, Fs08, Fs09, Fs10), only one individual of the variety Eucalyptoïdes (Fs16), located at In-Houter. The trees Fs01 to Fs07 have the same genotype, possibly linked to vegetative propagation.

The second cluster consisting of all individuals of the variety Teloukat located at IhAghi (Fs11, Fs12, Fs13, Fs14, Fs15) and at In-Zebib (Fs20), with 2 individuals of the variety Eucalyptoïdes at In-Zebib (Fs21, Fs22).

The third cluster included the variety Eucalyptoïdes from Tadadine (Fs17) and from In-Zebib (Fs23, Fs24, Fs25, Fs26), and then the variety Teloukat from Amezedjine (Fs38, Fs39).

The fourth cluster formed by all individuals of the variety Eucalyptoïdes located at In- Zebib (Fs27, Fs28, Fs29, Fs30, Fs31) and (Fs18) at Tadadine.

The fifth cluster containing all individuals of the variety Eucalyptoïdes located at In Zebib (Fs32, Fs33, Fs34, Fs35, Fs36, Fs37) and (Fs19) at Tadadine.

Figure 3 showed that the variety Teloukat was represented by short branches of the dendrogram, but the variety Eucalyptoïdes existed in the long branches.

To elucidate genetic relationships among the 39 fig genotypes, the Factorial Correspondence Analysis (FCA) confirmed information derived from the UPGMA clustering, so, the 2 dimensional scatter plot of factorial correspondence analysis coordinates for the first and second axis, showed a clear separation of the 2 varieties of Ficus salicifolia (Teloukat and Eucalyptoïdes) (Fig. 4); however the variety Tellouket was represented by two groups, probably related to the geographical origin of the genotypes.

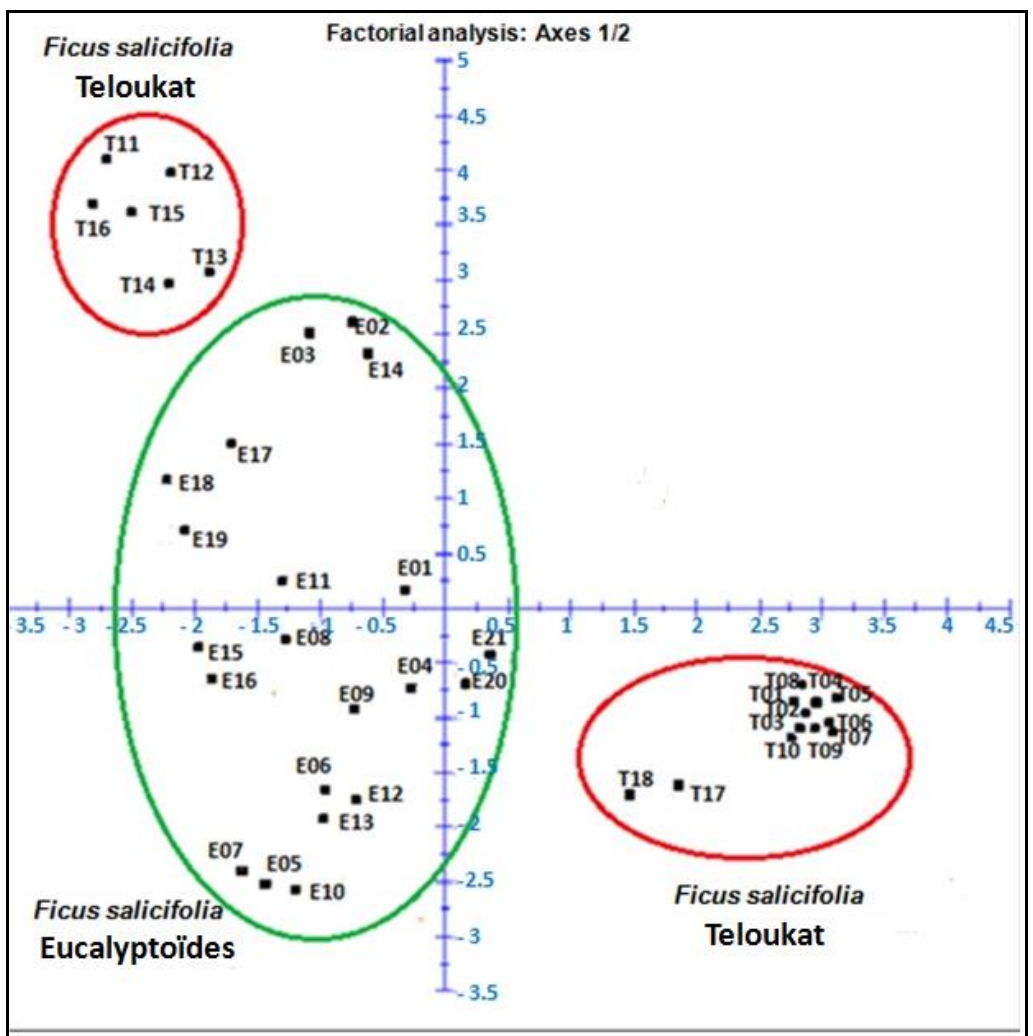

Figure 4. Factorial coordinate analysis (FCA), obtained by SSR markers of 39 south Algerian Fig trees. T, Teloukat; E, Eucalyptoides 


\section{Discussion}

The microsatellite markers were developed from different species of Ficus: Ficus carica (Khadari et al., 2001; Giraldo et al., 2005), Ficus inspida (Vignes et al., 2006), Ficus sycomorus (Ahmed et al., 2007), Ficus hirta (Zheng et al., 2015), Ficus tikoua (Zhang et al., 2016) and Ficus virens (Fu et al., 2017).

The high transferability of microsatellite markers developed from different subgenus of Ficus for Ficus citrifolia and Ficus eximia confirm the general applicability of Ficus microsatellite primers to this very large genus (Nazareno et al., 2009). Recently, Ikten et al. (2018), indicated a high level of transferability between Ficus carica and related Ficus species which provides growing number of SSR for Ficus carica; this would have important benefit for species with genomic studies are limited. Moreover, Hladnik et al. (2018) have studied the diversity parameters of selected microsatellites loci for use cultivar identification and fig genetic resources investigations.

In this study, we have made an attempt to use the utility of SSR markers in studying genetic diversity of species of figs, the performance of these markers was evaluated using various parameters such as observed heterozygosity (Ho), expected heterozygosity (He), Wright inbreeding coefficient (Fis) and Polymorphic information content (PIC).

The SSR loci applied in our analysis detected an average of 10.66 alleles, per locus in 39 individuals fig (Ficus salicifolia), which was higher than that found in SSR developed from the Ficus citrifolia 7.3 alleles per locus and Ficus eximia 6.4 alleles per locus (Nazareno et al., 2009), than from the Ficus carica: 5 alleles per locus (Achtak et al., 2009), 4.89 alleles per locus (Ferrara et al., 2016) and 4.2 alleles per locus (Leal et al., 2010). Giraldo et al. (2008) observed a low polymorphism within an ex situ Spanish figs collection, with 3.9 alleles per SSR locus; similarly, Teoman et al. (2017) also found 3.56 alleles per SSR locus within Turkish male and female fig genotypes.

Recently, Boudchicha et al. (2018) published a value of 3.59 alleles per locus within Algerian fig cultivars (Ficus carica). The variation in the number of alleles in fig species might be related to the difference in the SSR markers studied, as well as the number of samples and their geographic location (Lopes et al., 2004).

The 6 microsatellites loci used in this work were effective for the characterization of south Algerian fig species with high genetic diversity Ho $=0.61$. Achtak et al. (2009) reported that the average Ho value was 0.54 for the characterization of Moroccan cultivars figs; however Tunisian germplasm presents a high genetic diversity with Ho $=0.62$ (Ben Abdelkrim et al., 2015). Heterozygosity values of Ficus citrifolia and Ficus eximia reported by Nazareno et al. (2009) were respectively 0.67 and 0.69.

Moreover, the analysis of European and Asian fig cultivars showed a lower level of diversity with Ho $=0.44$ (Ikegami et al., 2009), similar results were obtained to characterize a collection of Turkish male and female fig genotypes with Ho $=0.45$ (Teoman et al., 2017) and Algerian fig cultivars (Ficus carica) with Ho $=0.46$ (Boudchicha et al., 2018), similarly, Giraldo et al. (2008) also determined low polymorphism within an ex situ Spanish collection figs with Ho $=0.41$.

According to the Hardy-Weinberg equilibrium (HWE), heterozygote excess $(\mathrm{Ho}>\mathrm{He})$ was observed for the MFC12 locus, and a deficiency of heterozygote $(\mathrm{Ho}<\mathrm{He})$ was observed in MFC2, MFC8, LMFC26, LMFC30 and FSYCO1 loci.

The average of polymorphism information content $(\mathrm{PIC}=0.70)$ is relatively the same compared with that of previous studies (Ikegami et al., 2009; Teoman et al., 2017). 
Fis values which is a measure of the deviation of genotypic frequencies from panmixia in population in term of heterozygous deficiency or excess, showed that loss of heterozygosity at just one microsatellite (MFC12). Fixation index values give an idea in terms of the inbreeding coefficient and individual differences.

This finding shows that most of the genetic diversity is caused by the difference between the two varieties of Ficus salicifolia as leaf morphology for instance: (the variety Teloukat: the leaves are oblong lanceolate, more or less strung at the base; the variety Eucalyptoides: the leaves are narrowly lanceolate, rounded or sub-attenuated at the base). According to our results, the SSR markers genotyping were in line with the phenotypic identification. The two groups of this variety observed might be linked to the geographical origin of the genotypes (Essid et al., 2015). However, for some groups, the individuals of the same variety were not well separated, probably due to the pollination of this species which is related to the pollinating insect (Jousselin et al., 2003), or to technical errors of the method of analysis used (absence of specific markers).

In addition, in natural habitats, Ficus salicifolia has substantially regressed with effects of climate changes; therefore, long term persistence of this taxon requires urgent preservation.

The microsatellite markers used in this study are highly polymorphic and efficient in revealing the level of genetic diversity studied; results from this investigation well demonstrate the capacity of SSR markers to separate genotype on 2 varieties from Ficus salicifolia (Teloukat and Eucalyptoïdes).

\section{Conclusion}

This study reports for the first time the characterization of two varieties of Ficus salicifolia, endangered fig species of southern Algeria. A high intra-specific polymorphism recorded by the microsatellite markers suggests their use to study the genetic diversity and the relationship between the different varieties and species of fig trees. This technique offers the ability to detect extensive polymorphisms by its simplicity and rapidity; furthermore, it is useful, to explore the genetic diversity of this important tree using other molecular markers.

Acknowledgements. This study was supported by General Direction of Scientific Research and Technological Development (DGRSDT) with the High Ministry of Research and Study (MESRS) of Algiers. We thank the members of Research Unit (UMR) 1098, Plant Development and Improvement DAP), and those of International Center for Agronomic Research for Development (CIRAD) Montpellier, France for their help in performing genetic study. Also, we thank all researchers of Research Laboratory of Arid Zones (LRZA), University of Sciences and Technology, Houari Boumediene, (USTHB/Algeria); University of Blida I for their help and especially guides of National Institute of Forest Research of Tamanrasset in collecting plant material.

\section{REFERENCES}

[1] Achtak, H., Oukabli, A., Ater, M., Santoni, S., Kjellberg, F., Khadari, B. (2009): Microsatellite markers as reliable tools for fig cultivar identification. - Journal of American Society for Horticultural Science 134: 624-631.

[2] Ahmed, S., Dawson, D. A., Compton, S. G., Gilmartin, P. M. (2007): Characterization of microsatellite loci in the African fig Ficus sycomorus L. (Moraceae). - Molecular Ecology Notes 7(6): 1175-1177. 
[3] Baali-Cherif, D., Besnard, G. (2005): High genetic diversity and clonal growth in relict populations of Olea europaea subsp. laperrinei (Oleaceae) from Hoggar, Algeria. Annals of Botany 96(5): 823-830.

[4] Bagavathiannan, M. V., Julier, B., Barre, P., Gulden, R. H., Van Acker, R. C. (2010): Genetic diversity of feral alfalfa (Medicago sativa L.) populations occurring in Manitoba, Canada and comparison with alfalfa cultivars: an analysis using SSR markers and phenotypic traits. - Euphytica 173(3): 419-432.

[5] Baraket, G., Chatti, K., Saddoud, O., Ben Abdelkarim, A., Mars, M., Trifi, M., Salhi Hannachi, A. (2011): Comparative assessment of SSR and AFLP Markers for evaluation of genetic diversity and conservation of Fig, Ficus carica L., Genetic Resources in Tunisia. - Plant Molecular Biology Reporter 29(1): 171-184.

[6] Battandier, M. J. A., Trabut, L. (1912): Contribution à la Flore du pays des Touaregs. Bulletin de la Société Botanique de France 58: 623-629.

[7] Baziar, G., Jafari, M., Sharifi Noori, M. S., Samarfard, S. (2018): Evaluation of genetic diversity among persian fig cultivars by morphological traits and RAPD markers. Journal of the American Society for Hoticultural Sciences 53: 613-619.

[8] Belkhir, K., Borsa, P., Goudet, J., Chikhi, L., Bonhomme, F. (2004): GENETIX v.4.05 logiciel sous Windows pour la génétique des populations. - Laboratoire Génome, Populations, Interactions CNRS UMR 5000, University of Montpellier II, Montpellier, France.

[9] Ben Abdelkrim, A., Baraket, G., Essalouh, L., Achtak, H., Khadari, B., Salhi-Hannachi, A. (2015): Use of morphological traits and microsatellite markers to characterize the Tunisian cultivated and wild figs (Ficus carica L.). - Biochemical Systematics and Ecology 59: 209-219.

[10] Ben Mohamed, M., Ben Ali, S., Boussora, F., Guasmi, F., Triki, T. (2017): Polymorphism of microsatellite (SSR) markers in Tunisian olive (Olea Europaea L.) cultivars. - Journal of Multidisciplinary Engineering Science Studies 3: 1247-1252.

[11] Berg, C. C. (1989): Classification and distribution of Ficus. - Experientia 45(7): 605-611.

[12] Boudchicha, R. H., Hormaza, J. I., Benbouza, H. (2018): Diversity analysis and genetic relationships among local Algerian fig cultivars (Ficus carica L.) using SSR markers. South African Journal of Botany 116: 207-215.

[13] Brzustowski, J. (2002): Clustering Calculator "Fast Clustering Algorithms, Including UPGMA and Saitou-Nei Neighbor Joining". - Department of Biological Sciences, University of Alberta, Canada.

[14] Dalkilic, Z., Mestav, H. O., Dalkilic, G. G., Kocatas, H. (2011): Genetic diversity of male fig (Ficus carica caprificus L.) genotypes with random amplified polymorphic DNA (RAPD) markers. - African Journal of Biotechnology 10(4): 519-526.

[15] Do Val, A. D. B., Souza, C. S., Ferreira, E. A., Salgado, S. M. L., Pasqual, M., Cançado, G. M. A. (2013): Evaluation of genetic diversity in fig accessions by using microsatellite markers. - Genetics and Molecular Research 12(2): 1383-1391.

[16] Ercisli, S., Orhan, E., Hizarci, Y., Yildirim, N., Agar, G. (2008): Genetic diversity in grapevine germplasm resources in the Coruh Valley revealed by RAPD markers. Biochemical Genetics 46: 590-597.

[17] Essid, A., Aljane, F., Ferchichi, A., Hormaza, J. I. (2015): Analysis of genetic diversity of Tunisian caprifig (Ficus carica) accessions using simple sequence repeat (SSR) markers. - Hereditas 152(1): 1-7.

[18] Ferrara, G., Mazzeo, A., Pacucci, C., Matarrese, A. M. S., Tarantino, A., Crisosto, C., Incerti, O., Marcotuli, I., Nigro, D., Blanco, A., Gadaleta, A. (2016): Characterization of edible fig germplasm from Puglia, south eastern Italy: is the distinction of tree fig types (Smyrna, San Pedro and Common) still valid? - Scientia Horticulturae 205: 52-58.

[19] Fu, R. H., Li, Y. X., Liu, M., Quan, Q. M. (2017): Development of 15 polymorphic microsatellite markers for Ficus virens (Moracea). - Applications in Plant Sciences 5(1): 1600101. 
[20] Giraldo, E., Viruel, M. A., Lopez-Corrales, M., Hormaza, J. I. (2005): Characterization and cross-species transferability of microsatellites in the common fig (Ficus carica L.). Journal of Horticultural Science and Biotechnology 80: 217-224.

[21] Giraldo, E., Lopez-Corrales, M., Hormaza, J. I. (2008): Optimization of the management of an ex-situ germplasm bank in common fig with SSRs. - Journal of the American Society for Horticultural Sciences 133: 69-77.

[22] Hladnik, M., Jakse, J., Khadari, B., Santoni, S., Bandelj, D. (2018): Interlaboratory comparison of Fig (Ficus carica L.) microsatellite genotyping data and determination of reference alleles. - Acta Agriculturae Slovenica 111-1: 143-159.

[23] Ikegami, H., Nogata, H., Hirashima, K., Awamura, M., Nakahara, T. (2009): Analysis of genetic diversity among European and Asian fig varieties (Ficus carica L.) using ISSR, RAPD, and SSR markers. - Genetic Resources and Crop Evolution 56: 201-209.

[24] Ikten, H., Solak, S. S., Yilmaz, Y. (2018): Transferability of SSR markers from related Ficus species to Ficus carica L. and assessment of effectiveness of the markers. Applied Ecology and Environmental Research 16(2): 1909-1919.

[25] Jousselin, E., Rasplus, J. Y., Kjelberg, F. (2003): Convergence and coevolution in a mutualism: evidence from a molecular phylogeny of Ficus. - Evolution 57(6): 12551269.

[26] Khadari, B., Hochu, I., Santoni, S., Kjellb erg, F. (2001): Identification and characterization of microsatellite loci in the common fig (Ficus carica L.) and representative species of genus Ficus. - Molecular Ecology Notes 1(3): 191-193.

[27] Khadari, B., Oukabli, A., Ater, M., Mamouni, A., Roger, J. P., Kjellberg, F. (2004): Molecular characterization of Moroccan fig germplasm using intersimple sequence repeat and simple sequence repeat markers to establish a reference collection. - Journal of the American Society for Horticultural Sciences 40: 29-32.

[28] Khadari, B., Grout, C., Santoni, S., Hochu, I., Roger, J. P., Ater, M., Aksoy, U., Kjellberg, F. (2005): Etude préliminaire des origines de Ficus carica L. et de sa domestication. - Les Actes du BRG 5: 53-65.

[29] Köse, M. A., Çetinsağ, N., Gürcan, K. (2017): De novo transcriptome assembly and SSR marker development in apricot (Prunus armeniaca). - Turkish Journal of Agriculture and Forestry 41: 305-315.

[30] Leal, A. A., Mangolin, C. A., Do Amaral, A. T. J. R., Gonçalves, L. S., Scapim, C. A., Mott, A. S., Eloi, I. B., Cordovés, V., Da Silva, M. F. (2010): Efficiency of RAPD versus SSR markers for determining genetic diversity among popcorn lines. - Genetics and Molecular Research 9(1): 9-18.

[31] Licea-Moreno, R. L., Quintana, J., Contreras, A., Gomez, L. (2019): Using SSR markers from Prunus genus for wild cherry genotyping. - Genetics and Biodiversity Journal 3(1): $1-9$.

[32] Lopes, M. S., Mendonça, D., Sefc, K. M., Sabino, G. F., Câmara Machado, A. (2004): Genetic evidence of intra-cultivar variability within Iberian olive cultivars. - Journal of the American Society for Horticultural Sciences 39: 1562-1565.

[33] Marshall, T. C. (1998): Cervus. (Version 3.0) [Cervus is a computer program for the assignment of parents to their offspring using genetic markers. Cervus, a Windows package for parentage analysis using likelihood approach].

[34] Nazareno, A. G., Pereira, R. A. S., Feres, J. M., Mestriner, M. A., Alzate-Martin, A. L. (2009): Transferability and characterization of microsatellite markers in two Neotropical Ficus species. - Genetics and Molecular Biology 32(3): 568-571.

[35] Ozenda, P. (1977): Flore du Sahara. $2^{\text {eme }}$ Ed. - Centre National de la Recherche Scientifique (CNRS), Paris.

[36] Perrier, X., Flori, A., Bonnot, F. (2003): Data Analysis Methods. - In: Hamon, P., Seguin, M., Perrier, X., Glaszmann, J. C. (eds.) Genetic Diversity of Cultivated Tropical Plants. Science Publishers, Enfield, pp. 43-76. 
[37] Pikunova, A. V., Sedov, E., Tokmakov, E. V., Suprun, I. I., Gorbatchova, N. G., Dolzhikova, M. A., Yanchuk, T. V., Serova, Z. M. (2018): Microsatellite Loci Polymorphism of Apple (Malus domestica Borkh.) Genotypes with different Ploidy Level. - Russian Journal of Genetics 54(4): 442-450.

[38] Sahki, A., Sahki, R. (2004): Le Hoggar: Promenade botanique. - Ésope Chamonix, Lyon.

[39] Saitou, N., Nei, M. (1987): The neighbor-joining method: a new method for reconstructing phylogenetic trees. - Molecular Biology and Evolution 4: 405-425.

[40] Sambrook, J., Fritsch, E. F., Maniatis, T. (1989): Molecular Cloning: A Laboratory Manual. Second Ed. - Cold Spring Harbor Laboratory Press, New York.

[41] Tamura, K., Nei, N. (1993): Estimation of the number of nucleotide substitutions in the control region of mitochondrial DNA in humans and chimpanzees. - Molecular Biology and Evolution 10: 512-526.

[42] Teoman, S., Ipek, M., Erturk, U., Aktepe tangu, N., Durgut, E., Barut, E., Ercisli, S., Ipek, A. (2017): Assessment of genetic relationship among male and female fig genotypes using simple sequence repeat (SSR) markers. - Notulae Botanicae Horti Agrobotanici 45(1): 172-178.

[43] Vignes, H., Hossaert-McKey, M., Beaune, D., Fevre, D., Anstett, M. C., Borges, R. M., Kjellberg, F., Chevallier, M. H. (2006): Development and characterization of microsatellite markers for a monoecious Ficus species, Ficus insipida, and cross-species amplification among different sections of Ficus. - Molecular Ecology Notes 6: 792-795.

[44] Weir, B. S., Cockerham, C. C. (1984): Estimating F-statistics for the analysis of population structure. - Evolution 38: 1358-1370.

[45] Zhang, L. G., Tan, L., Hu, D. M., Chen, Y. (2016): Development of 14 polymorphic microsatellite loci for Ficus tikoua (Moracea). - Applications in Plant Sciences 4(3): 1500099.

[46] Zheng, L., Nason, J. D., Liang, D., Ge, X., Yu, H. (2015): Development and characterization of microsatellite loci for Ficus hirta (Moraceae). - Applications in Plant Sciences 3(7): 1500034.

\section{APPENDIX}

Appendix 1. List of individual fig trees with GPS information

\begin{tabular}{|c|c|c|c|c|c|c|}
\hline $\begin{array}{l}\text { Local name of } \\
\text { collection zones }\end{array}$ & $\begin{array}{c}\text { Number of } \\
\text { trees }\end{array}$ & $\begin{array}{c}\text { Code of } \\
\text { trees }\end{array}$ & $\begin{array}{l}\text { Code of } \\
\text { varieties }\end{array}$ & Altitude (m) & Latitude & Longitude \\
\hline TIT & 10 & $\begin{array}{l}\text { Fs01 } \\
\text { Fs02 } \\
\text { Fs03 } \\
\text { Fs04 } \\
\text { Fs05 } \\
\text { Fs06 } \\
\text { Fs07 } \\
\text { Fs08 } \\
\text { Fs09 } \\
\text { Fs10 }\end{array}$ & $\begin{array}{l}\text { T01 } \\
\text { T02 } \\
\text { T03 } \\
\text { T04 } \\
\text { T05 } \\
\text { T06 } \\
\text { T07 } \\
\text { T08 } \\
\text { T09 } \\
\text { T10 }\end{array}$ & $\begin{array}{l}1086 \\
1085 \\
1086 \\
1081 \\
1084 \\
1081 \\
1084 \\
1081 \\
1088 \\
1082\end{array}$ & $\begin{array}{l}22^{\circ} 57^{\prime} 54^{\prime \prime} \\
22^{\circ} 57^{\prime} 54^{\prime \prime} \\
22^{\circ} 57^{\prime} 54^{\prime \prime} \\
22^{\circ} 57^{\prime} 54^{\prime \prime} \\
22^{\circ} 57^{\prime} 54^{\prime \prime} \\
22^{\circ} 57^{\prime} 55^{\prime \prime} \\
22^{\circ} 57^{\prime} 38^{\prime \prime} \\
22^{\circ} 57^{\prime} 38^{\prime \prime} \\
22^{\circ} 57^{\circ} 55^{\circ} 57^{\prime} 55^{\prime \prime}\end{array}$ & $\begin{array}{l}05^{\circ} 09^{\prime} 73^{\prime \prime} \\
05^{\circ} 09^{\prime} 73^{\prime \prime} \\
05^{\circ} 09^{\prime} 73^{\prime \prime} \\
05^{\circ} 09^{\prime} 73^{\prime \prime} \\
05^{\circ} 09^{\prime} 72^{\prime \prime} \\
05^{\circ} 09^{\prime} 72^{\prime \prime} \\
05^{\circ} 09^{\prime} 81^{\prime \prime} 09^{\prime} 73^{\prime \prime} \\
05^{\circ} 09^{\prime} 81^{\prime \prime} \\
05^{\circ} 09^{\prime} \\
05^{\circ}\end{array}$ \\
\hline IH-AGHI & 05 & $\begin{array}{l}\text { Fs11 } \\
\text { Fs12 } \\
\text { Fs13 } \\
\text { Fs14 } \\
\text { Fs15 }\end{array}$ & $\begin{array}{l}\text { T11 } \\
\text { T12 } \\
\text { T13 } \\
\text { T14 } \\
\text { T15 } \\
\end{array}$ & $\begin{array}{l}1093 \\
1095 \\
1094 \\
1093 \\
1094 \\
\end{array}$ & $\begin{array}{l}23^{\circ} 04^{\prime} 10^{\prime \prime} \\
23^{\circ} 04^{\prime} 10^{\prime \prime} \\
23^{\circ} 04^{\prime} 10^{\prime \prime} \\
23^{\circ} 04^{\prime} 10^{\prime \prime} \\
23^{\circ} 04^{\prime} 10^{\prime \prime}\end{array}$ & $\begin{array}{l}05^{\circ} 12^{\prime} 85^{\prime \prime} \\
05^{\circ} 12^{\prime} 84^{\prime \prime} \\
05^{\circ} 12^{\prime} 84^{\prime \prime} \\
05^{\circ} 12^{\prime} 84^{\prime \prime} \\
05^{\circ} 12^{\prime} 85^{\prime \prime}\end{array}$ \\
\hline IN-HOUTER & 01 & Fs16 & E01 & 1455 & $23^{\circ} 04^{\prime} 73^{\prime \prime}$ & $05^{\circ} 22^{\prime} 85^{\prime \prime}$ \\
\hline
\end{tabular}




$$
-3835 \text { - }
$$

\begin{tabular}{|c|c|c|c|c|c|c|}
\hline TADADINE & 03 & $\begin{array}{l}\text { Fs17 } \\
\text { Fs18 } \\
\text { Fs19 }\end{array}$ & $\begin{array}{l}\text { E04 } \\
\text { E11 } \\
\text { E20 }\end{array}$ & $\begin{array}{l}1315 \\
1330 \\
1350\end{array}$ & $\begin{array}{l}22^{\circ} 49^{\prime} 42^{\prime \prime} \\
22^{\circ} 49^{\prime} 42^{\prime \prime} \\
22^{\circ} 49^{\prime} 43^{\prime \prime}\end{array}$ & $\begin{array}{l}05^{\circ} 57^{\prime} 33^{\prime \prime} \\
05^{\circ} 57^{\prime} 32^{\prime \prime} \\
05^{\circ} 57^{\prime} 33^{\prime \prime}\end{array}$ \\
\hline IN-ZEBIB & 18 & $\begin{array}{l}\text { Fs 20 } \\
\text { Fs21 } \\
\text { Fs22 } \\
\text { Fs23 } \\
\text { Fs24 } \\
\text { Fs25 } \\
\text { Fs26 } \\
\text { Fs27 } \\
\text { Fs28 } \\
\text { Fs29 } \\
\text { Fs30 } \\
\text { Fs31 } \\
\text { Fs32 } \\
\text { Fs33 } \\
\text { Fs34 } \\
\text { Fs35 } \\
\text { Fs36 } \\
\text { Fs33 }\end{array}$ & $\begin{array}{l}\text { T16 } \\
\text { E02 } \\
\text { E03 } \\
\text { E05 } \\
\text { E06 } \\
\text { E07 } \\
\text { E08 } \\
\text { E09 } \\
\text { E10 } \\
\text { E12 } \\
\text { E13 } \\
\text { E14 } \\
\text { E15 } \\
\text { E16 } \\
\text { E17 } \\
\text { E18 } \\
\text { E19 } \\
\text { E21 }\end{array}$ & $\begin{array}{l}1431 \\
1425 \\
1435 \\
1441 \\
1456 \\
1449 \\
1433 \\
1428 \\
1451 \\
1446 \\
1459 \\
1428 \\
1454 \\
1452 \\
1458 \\
1440 \\
1448 \\
1447\end{array}$ & $\begin{array}{l}22^{\circ} 48^{\prime} 17^{\prime \prime} \\
22^{\circ} 48^{\prime} 36^{\prime \prime} \\
22^{\circ} 48^{\prime} 16^{\prime \prime} \\
22^{\circ} 48^{\prime} 42^{\prime \prime} \\
22^{\circ} 48^{\prime} 43^{\prime \prime} \\
22^{\circ} 48^{\prime} 57^{\prime \prime} \\
22^{\circ} 48^{\prime} 28^{\prime \prime} \\
22^{\circ} 48^{\prime} 42^{\prime \prime} \\
22^{\circ} 48^{\prime} 43^{\prime \prime} \\
22^{\circ} 48^{\prime} 41^{\prime \prime} \\
22^{\circ} 48^{\prime} 43^{\prime \prime} \\
22^{\circ} 48^{\prime} 42^{\prime \prime} \\
22^{\circ} 48^{\prime} 43^{\prime \prime} \\
22^{\circ} 48^{\prime} 43^{\prime \prime} \\
22^{\circ} 48^{\prime} 44^{\prime \prime} 48^{\prime} 26^{\prime} \\
22^{\circ} 48^{\prime} 35^{\prime} " \\
22^{\circ} 8^{\circ} 57^{\prime}\end{array}$ & $\begin{array}{l}05^{\circ} 37^{\prime} 22^{\prime \prime} \\
05^{\circ} 37^{\prime} 13^{\prime \prime} \\
05^{\circ} 37^{\prime} 20^{\prime \prime} \\
05^{\circ} 37^{\prime} 27^{\prime \prime} \\
05^{\circ} 37^{\prime} 26^{\prime \prime} \\
05^{\circ} 37^{\prime} 04^{\prime \prime} \\
05^{\circ} 37^{\prime} 34^{\prime \prime} \\
05^{\circ} 37^{\prime} 22^{\prime \prime} \\
05^{\circ} 37^{\prime} 28^{\prime \prime} \\
05^{\circ} 37^{\prime} 89^{\circ} \\
05^{\circ} 37^{\prime} 27^{\circ} 37^{\prime} 22^{\prime \prime} \\
05^{\circ} 37^{\prime} 24^{\prime \prime} \\
05^{\circ} 37^{\circ} 26^{\prime} \prime \\
05^{\circ} 37^{\prime} 61^{\prime \prime} 37^{\prime} 04^{\prime \prime} \\
05^{\circ} 37^{\prime} 94^{\prime \prime}\end{array}$ \\
\hline AMEZEDJINE & 02 & $\begin{array}{l}\text { Fs38 } \\
\text { Fs39 }\end{array}$ & $\begin{array}{l}\text { T17 } \\
\text { T18 }\end{array}$ & $\begin{array}{l}1162 \\
1165\end{array}$ & $\begin{array}{l}22^{\circ} 36^{\prime} 96^{\prime \prime} \\
22^{\circ} 36^{\prime} 96^{\prime \prime}\end{array}$ & $\begin{array}{l}05^{\circ} 24^{\prime} 46^{\prime \prime} \\
05^{\circ} 24^{\prime} 46^{\prime \prime}\end{array}$ \\
\hline
\end{tabular}

Fs, Ficus salicifolia, T, Teloukat; E, Eucalyptoides 